\title{
THE KNOWLAND AMENDMENT: A POTENTIAL THREAT TO FEDERAL UNEMPLOYMENT COMPENSATION STANDARDS
}

Tне Social Security Act of 1935 has prodded all 48 states into establishing unemployment compensation schemes which conform to basic Congressional standards. ${ }^{1}$ The Act imposes a federal payroll tax of $3 \%$ upon employers of more than 8 persons. $^{2}$ These employers can, however, credit against $90 \%$ of their federal tax any contributions made to a state unemployment compensation scheme, provided the state plan meets federal standards. ${ }^{3}$ In addition to certain fiscal and organizational requirements, ${ }^{4}$ state plans must include three labor safeguards to qualify employers for tax credits. These safeguards are designed to insure that state compensation officials will not use unemployment benefits to undermine union activity. Tax credits can be cut off if the state denies benefits to otherwise eligible workers who refuse to accept (a) jobs in strikebound plants, (b) substandard work, or (c) employment which requires them to sign yellow dog contracts, join company unions, or resign from bona fide unions. ${ }^{5}$

1. AtKinson, The Federal Role in Unemployment Compensation AdmintsTRATION 5 (1941). The territories have also adopted unemployment compensation plans in response to the Act. Before the passage of the Act only Wisconsin had enacted such legislation, although attempts had been made in several other states. Dougcas, P. H., Social Security In the United States 12-21 (1936).

Congress might have adopted a nationally-administered system of unemployment compensation similar to the federal old-age-insurance program. Instead it chose to allow the states leeway in formulating their own administrative procedures and substantive requirements. The administrative complexities of carrying out unemployment insurance schemes would have necessitated a larger federal staff than old-age-insurance. For general discussions of the present unemployment compensation system's underlying principles of state-federal cooperation, see DougLas, supra, c. V; ATKINson, supra, c. I.

2. INT. REv. CoDE $\$ 1600$. The original Act provided that the rates were to accelerate. Thus the tax imposed for 1936 was one per cent of the total payroll; for 1937 it was two per cent; and after December 31, 1937, the rate was to remain at three per cent. 49 STAT. 639 (1935), 26 U.S.C. $\$ 1600$ (1946).

3. INT. REv. Code $\$ 1601$ (a) and (c).

The Social Security Act also provides for grants of federal funds to the states to defray the costs of administering their unemployment compensation systems. 49 Stat. 626 (1935), 42 U.S.C. $\$ 501$ (1946). To qualify for this assistance, state agencies must comply with uniform personnel and administrative requirements. 42 Stat. 626 (1935), 42 U.S.C. $\$ 503(\mathrm{a})$ (1946). These grants, coupled with the $90 \%$ tax credit, provided the principal incentive for states to set up unemployment compensation systems.

4. INT. REv. CODE $\$ 1603$ (a) (1), (2), (3), and (4). These sections require the states to pay out all compensation through public employment offices or other agencies acceptable to the Secretary of Labor. No benefits can be disbursed until two years after a state first exacts contributions from employers. Furthermore, the states must invest funds derived from these contributions in the Unemployment Trust Fund under the control of the Secretary of the Treasury. Withdrawals can be made only as needed for compensation payments.

5. INT. REv. CoDE $\$ 1603(a)(5)$ : "Compensation shall not be denied in such State to any otherwise eligible individual for refusing to accept new work under any of the 
At the end of each year, the Secretary of Labor must certify to the Secretary of Treasury those states whose unemployment plans meet the Congressional tests for tax credits. ${ }^{6}$ Whenever the Secretary believes that a state is violating the labor standards, he negotiates with the state authorities through his subordinates in the Unemployment Insurance Service. ${ }^{7}$ In case of a deadlock in negotiations, the original Act authorized the Secretary to call a hearing to determine whether the state, first, had "so changed its law" that the law no longer met the federal standards or, second, had "failed to comply substantially" with those standards. ${ }^{8}$ A finding against the state on either count justified the revocation of tax credits to employers within that state.

following conditions: (A) If the position offered is vacant due directly to a strike, lockout, or other labor dispute; (B) if the wages, hours, or other conditions of the work offered are substantially less favorable to the individual than those prevailing for similar work in the locality; (C) if as a condition of being employed the individual would be required to join a company union or to resign from or refrain from joining any bona fide labor organization;"

6. INT. REv. CODE $\S 1603(\mathrm{c})$. This function was originally vested in the Social Security Board of three members. When that body was abolished in 1946, its duties were transferred to the Federal Security Administrator. 1946 Reorg. Plan No. 2, 4, eff. July 16,$1946 ; 60$ Stat. 1095 (1946), 42 U.S.C. $\$ 503$ (1946). More recently all the functions of the Federal Security Administrator with respect to unemployment compensation were given to the Secretary of Labor. 1949 Reorganization Plan No. 2, 1, eff. Aug. 19, 1949; 14 FEd. REg. 5225 (1949), 63 Stat. 1065 (1949).

7. The Unemployment Insurance Service, a part of the Bureau of Employment Security, was transferred to the Department of Labor from the Federal Security Agency by Reorganization Plan No. 2 of 1949. The purpose of the shift was to place activities primarily concerned with labor problems under one roof. Hearings before the Committee on Expenditures in the Executive Departments on $H$. Res. 301, 81st Cong., 1st Sess. (1949). Opponents of Reorganization Plan No. 2 feared the partiality of the Secretary of Labor. 95 Cong. Rec. 11598-601 (1949).

The Unemployment Insurance Service has handled problems of conformity with the federal standards since the passage of the Social Security Act. At present it maintains 13 regional offices. Officials in the Service examine state administrative rulings on the appellate level and court decisions to see that they are in accord with federal requirements. The Service answers inquiries from state administrators and advises them on legislation and decisions. The states submit certified copies of all legislation relating to unemployment compensation and benefit rulings. The most important of these decisions are published for the convenience of state authorities in the Benefit Series Service. Representatives of the Service also inspect state agencies at yearly intervals. Communication to the YaLe LAW Journal from R. G. Wagenet, Assistant Director of the Bureau of Employment Security, dated April 30,1951, on file in Yale Law Library. See also Atiminson, op. cit. supra note 1, 38-41; Att'y Gen. Comm. Ad. Proc., Social Security Board, Sen. Doc. No. 10, PART 16, 77th Cong., 1st Sess. 60-62 (1940).

8. INT. REv. CoDE $\$ 1603$ (c); "On December 31 of each taxable year the Secretary of Labor shall certify to the Secretary each State whose law he has previously approved, except that he shall not certify any State which, after reasonable notice and opportunity for hearing to the State agency, the Secretary of Labor finds has changed its law so that it no longer contains the provisions specified in subsection (a) or has with respect to such taxable year failed to comply substantially with any such provision." Although 
In recent months this hearing machinery has come into new prominence. In the fifteen-year period 1935-49, only one hearing was held to determine whether the labor standards had been violated. In that case the Oregon legislature had amended its unemployment compensation law. ${ }^{9}$ But then in the single month of December 1949, two federal hearings were called to consider alleged violations by state administrative officials. ${ }^{10}$ The Secretary of Labor, newly appointed to the job of supervising unemployment compensation administration, ${ }^{11}$ sought to determine if the California and Washington unemployment agencies had "so changed the law" as to deviate from federal standards. Both agencies had issued administrative ruling denying benefits to certain maritime workers who refused strike-bound jobs. Although the California hearing was subsequently terminated when the state assured the Secretary that it would change its policy in the future, he went on to make findings in the Washington case that benefits had been denied workers solely

the weapon of disqualifying a state for tax credit purposes has been characterized as "very clumsy" by one commentator, Douglas, op. cit. supra note 1 at 137, the threat of its use appears to have been a substantial factor in keeping the states in line.

The Secretary may similarly deprive a state of its grant for administrative expenses if he finds, after a hearing, that there has been either of the following: "( 1 ) a denial in a substantial number of cases, of unemployment compensation to individuals entitled thereto under such [state] law; or (2) failure to comply with the provisions of subsection (a) [administrative standards]" 49 STAT. 626 (1935), 42 U.S.C. § 503(b) (1946). No hearing has ever been held under this provision.

The meaning of the phrase "failed to comply substantially" in INT. Rev. Code $\$ 1603$ (c) has never been determined. It might be interpreted to mean failure to comply in a "substantial number of cases," similar to the provision for cutting off federal grants for state administrative expenses, 42 U.S.C. $\$ 503(\mathrm{~b})(1)$ (1946). A more reasonable interpretation of the phrase would be failure to comply in a material way even if only a single violation by the state agency were involved. This interpretation would be justified by the different wording of the two sections.

There is no provision for judicial review of the Secretary's decision under INT. REV. CODE $\$ 1603$ (c). Such review was proposed by Senator Cain in his statement supporting the Knowland Amendment. 96 CoNG. REc. 8885 (1950). The Bureau of Employment Security is on record as supporting the principle of judicial review. It feels that judicial interpretation of phrases such as "comply substantially" and of the Knowland Amendment would be desirable. Communication to the YALE LAW Journal from R. G. Wagenet, supra note 7 .

9. Communication to YALE LAw Journal from Maurice J. Tobin, Secretary of Labor, dated November 8, 1950, in Yale Law Library. This hearing was held before the Social Security Board in 1939 to determine whether Oregon had "so changed its lav" that it no longer met the federal standards. When the Oregon legislature passed another amendment making it clear that the federal standards would be observed, the state was declared to be in conformity. Social Security Board: Matter of Hearings pursuant to section $903(b)$ of the Social Security Act concerning changes in the Oregon Unemployment Compensation Law. See also Att'y Gen. Comm. Ad. Proc., stipra note 7 at 61 .

10. Communication to the Yale LAw Journal from Maurice J. Tobin, supra note 9.

11. See note 6 supra. 
because they refused strike-bound jobs. He threatened to cut off tax credits from Washington employers. Faced with the imminence of substantial tax losses to its employers, the Washington agency agreed to comply with the Secretary's findings. ${ }^{12}$

State unemployment officials, impressed by the narrow margin by which Washington employers had escaped double taxation, sought action from Congress. They argued that the Secretary of Labor, who now possessed the powers of the old three-man bipartisan Social Security Board, might upset state unemployment administration by wielding those powers too often and too hastily. ${ }^{13}$

An amendment to the federal Act, sponsored by Senator Knowland of California and strongly supported by Senator Cain of Washington, was drafted to meet the fears of these officials. Introduced on the floor of the Senate ${ }^{14}$ without prior committee hearings, ${ }^{15}$ it passed Congress as a "rider" to the Social Security Act Amendments of $1950 .^{16}$ The Knowland amendment

12. Untited States Department of Labor: In the Matter of Hearings to Determine the Conformity of the Washington Unemployment Compensation Act; Communication to the YaLE Law JourNal from Maurice J. Tobin, supra note 9. The Washington case concerned rulings issued by the Appeal Tribunal of the Washington agency which withheld benefits from members of maritime unions and a carpenters' union. These unions had called strikes at a time when some members were unemployed for reasons unrelated to the labor dispute. These members had been drawing benefits prior to the strike. Although they did not assist in strike activities, their benefits were cut off by the agency at the commencement of the walkouts. The agency jusified its action on the ground that these persons could have secured jobs with their former employers now that their fellow union members were out on strike. Thus the workers involved were given the choice of becoming strikebreakers against their own unions or going without compensation. The agency's decisions were based on a provision of state law.

At the time the Secretary called a hearing, 14 FED. REG. 7166 (1950), the rulings had been confirmed by the Washington Unemployment Commissioner, the ultimate authority within the agency. Under Washington law an appeal to the courts must be taken 30 days after a decision by the Commissioner, and that period had expired. WASH. Rev. Stat. \$9998-106(h),(i).(Remington Supp. 1941).

13. See the statements of Senator Knowland, 96 CoNG. REc. 8885 (1950). He introduced into the record letters and telegrams from state officials urging Congressional action. 96 CoNG. ReC. 8783-84 (1950).

14. 96 Cong. Rec. 8883 (1950).

15. See the statement of Senator Lehman of New York, 96 CoNg. Rec. 8886 (1950): "I understand that an effort was made to bring this matter before the Committee on Finance during its deliberations on H.R. 6000. The committee, however, refused to take action on this amendment."

16. The amendment passed the Senate 45-37. 96 Cong. Rec. S8S7 (1950). The conference committee included it in the Social Security Amendment Bill, H.R. 6000, 81st Cong., 2d Sess. (1950), at the insistence of the Senate members. Therefore the House never voted on the amendment apart from the entire bill. In presenting H.R. 6000 to the House, the House conferees made the following statement: "The Conference agreement is intended as a temporary measure of a stop gap nature pending reexamination by the appropriate committee during the next session of Congress of 
changes federal enforcement procedure of the labor standards in several ways. It modifies the Secretary's first grant of power by requiring that a state "amend" rather than merely "change" its law before the Secretary can schedule a hearing. ${ }^{17}$ Apparently only legislative action can meet this requirement. Where the state action is administrative, on the other hand, as in the California and Washington cases, the Secretary can call a hearing only under his second grant of power-i.e., by charging a failure to "comply substantially" with the federal standards. But in that case, the Knowland amendment prohibits the Secretary from finding such a failure until the benefit claimants have exhausted their state administrative and judicial remedies. ${ }^{18}$ This provision was interpreted by both the supporters and opponents of the amendment as forbidding the Secretary from acting on the basis of administrative action which has not been sanctioned by state courts. ${ }^{19}$ Finally, the amendment provides that the Secretary's finding that a state scheme does not meet the

the whole field of unemployment insurance legislation to ascertain the desirability of appropriate permanent legislation." 96 CoNG. REC. 12646 (1950); H.R. REP. No. 2771, 81 st Cong., 2d Sess. 122 (1951). President Truman signed the Social Security Amendment Bill, which included the Knowland Amendment, on August 28, 1950. It became Pub. L. No. 734, 81st Cong., 2d Sess. (1950).

17. Id. $\S 405(\mathrm{a})(1)$.

18. Id. $\$ 405$ (a) (2). This subsection adds the following proviso to INT. REv. ConE $\S 1603$ (c): "No finding of a failure to comply substantially with the provision in State law specified in paragraph (5) of subsection (a) [the labor standards] shall be based on an application or interpretation of State law with respect to which further administrative or judicial review is provided for under the laws of the State." In contrast, the Secretary's power to cut off tax credits for failure to comply with the federal fiscal and organizational standards, supra note 4, has been left unimpaired.

The Knowland Amendment imposes a similar restriction upon the Secretary's power to cut off federal grants for state administrative costs, supra note 8:

"Provided, That there shall be no finding under clause (1) until the question of entitlement shall have been decided by the highest judicial authority given jurisdiction under such laws:"

His power with respect to clause (2), which refers to violations of administrative standards, is not affected. Violations of the labor safeguards are embraced within clause (1).

19. See the statement of Senator Knowland, 96 CoNG. Rec. 8884 (1950): "It [the amendment] says to the Secretary of Labor that he must base his costly-in every sense of the word-decision of non-conformity with Federal statutory requirements only upon interpretations of State law which are made by the courts of the States involved. . . It simply postpones action by the Secretary of Labor until the State judiciary has spoken. ..." Senator Lehman, who opposed the amendment, seemed to be interpreting it in the same way when he stated: "Under the amendment of the Senator from California, the unemployment-compensation authorities of a State could interpret their unemployment-compensation law in a manner wholly at variance from the clear intent of the language of the law, and the Secretary of Labor would be powerless to raise any question of whether that law continues to conform with the requirements laid down by Congress." Id. at 8886 . 
federal standards is not to become effective until 90 days after he has notified the governor of the state. ${ }^{20}$

Some of these provisions may improve federal supervision of state unemployment compensation programs. The requirement of exhaustion of administrative remedies merely codifies the Secretary's existing practice. For in both the Washington and California cases, he waited until the claimants had exhausted their administrative remedies before even calling a hearing. Nevertheless, it may be helpful to have this practice written into law, to rule out the possibility of rash action by an over-zealous Secretary of Labor. The 90-day waiting period assures employers an opportunity to urge the state agency to reverse its ruling or the legislature to amend the state statute. This seems a reasonable way to protect employers against precipitate action by state administrators.

However, the amendment's further requirement-that claimants exhaust their state judicial remedies-is potentially harmful to prompt and efficient enforcement of the federal labor standards. In every state a claimant denied unemployment benefits can appeal to the courts. ${ }^{21}$ But he may not avail himself of this remedy. Appeals are expensive and time-consuming. Many workers do not have the funds to prosecute them. ${ }^{22}$ Unions may help their members to finance appeals, but unorganized workers lack such support. Yet the net result of failure to take an appeal is to block the Secretary from enforcing the federal standards. He could not have made findings in the Washington case, for example, because the claimants' appeal time had already run when he called his hearing. Furthermore, even when an appeal is taken, a final decision may not come down for months or years after the initial administrative ruling. Many state courts have notoriously crowded dockets.

Realizing these possibilities for delay, recalcitrant state officials may in the future be somewhat more prone to violate the federal standards. It is impossible at this point to forecast accurately how great the amendment's influence will be in this respect. The Unemployment Insurance Service, whenever it believes that state administrators are violating the federal standards, can still negotiate with them. If they do not accede to the Service's

20. Pub. L. No. 734, 81st Cong., 2nd Sess. 809 (Aug. 28, 1950). This section adds the following phrase to INT. REv. CODE $\$ 1603$ (c) : "Such finding shall become effective on the ninetieth day after the Governor of the State has been notified thereof unless the State has before such ninetieth day so amended its law that it will comply substantially with the Secretary of Labor's interpretation of the provision of subsection (a) [the labor standards], in which event such finding shall not become effective."

21. Wagenet, Analysis of State Unemployment Conpensation Laws (1937).

22. The Knowland Amendment contains a provision specifying that "any costs may be paid with respect to any claimant by a state and included as costs of administration of its law." Pub. L. No. 734, 81st Cong., 2d Sess. 809, $\$ 405$ (b) (Aug. 28, 1950). This might be interpreted to mean that a state san, if it wishes, pay a claimant's court costs and in turn be reimbursed by the federal government. But more likely it means that a state agency's costs in defending an appeal will be paid by the federal government. 